\title{
Immediate versus delayed primary repair of the sciatic nerve in a nerve transaction model in rats
}

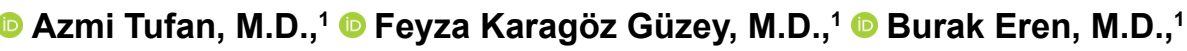

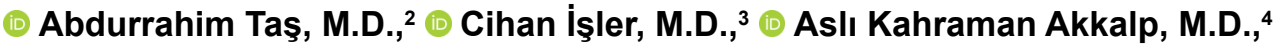 \\ (1) İlker Güleç, M.D., ${ }^{1}$ (1) Vildan Ayşe Yayla, M.D., ${ }^{5}$ (1) Murat Çabalar, M.D. ${ }^{5}$
}

\begin{abstract}
${ }^{1}$ Department of Neurosurgery, Health Sciences University, Bağcılar Training and Research Hospital, İstanbul-Turkey
${ }^{2}$ Department of Neurosurgery, Health Sciences University, Gazi Yaşargil Training and Research Hospital, Diyarbakır-Turkey

${ }^{3}$ Department of Neurosurgery, İstanbul University-Cerrahpaşa, Cerrahpaşa Faculty of Medicine, İstanbul-Turkey

${ }^{4}$ Department of Pathology, İzmir Katip Çelebi University Atatürk Training and Research Hospital, İzmir-Turkey

${ }^{5}$ Department of Neurology, Health Sciences University, Bakirköy Dr. Sadi Konuk Training and Research Hospital, İstanbul-Turkey
\end{abstract}

\section{ABSTRACT}

BACKGROUND: The debate continues concerning surgical timing in a peripheral nerve injury. This study aims to evaluate the result of immediate versus delayed primary (after seven days) repair of peripheral nerve injury.

METHODS: In this study, Wistar rats were divided into four groups as follows: The nerve was sharply transected in Group I, 2 and 4. It was immediately sutured in Group I and sutured seven days later in Group 2, and it was not sutured in Group 4. In Group 3, the left sciatic nerve was only explored. Eight weeks later, tissue samples were extracted from the injured nerve area. Both gastrocnemius muscles were weighed. The nerve samples were examined for axon degeneration. Myelin vacuolization, axon irregularity, and edema/ inflammation parameters were evaluated.

RESULTS: There were not any significant differences in the score of axon degeneration and the weight of the gastrocnemius muscle between the immediate and delayed primary repair groups. However, these parameters were significantly better in both repair groups than to be in the control group and significantly worse than to be in the sham-operated group.

CONCLUSION: To delay the repair about one week did not affect the histological results and weight of the muscle that was innervated by the sectioned nerve comparing to be in the immediate repair in a sciatic nerve transaction model in rats.

Keywords: Nerve injury; nerve transaction; peripheral nerve; peripheral nerve injury; timing of the operation.

\section{INTRODUCTION}

Peripheral nerve injury is a serious public health problem because it frequently occurs in young and productive people, and it may cause serious disabilities. Surgical treatment is mandatory in almost all of the patients with nerve transaction.

The most preferred surgical method for the treatment of peripheral nerve transaction with sharp objects is the primary end-to-end suturing of the proximal and distal nerve ends. There are many studies advocating immediate surgery in these cases in the literature because the best results occur with this timing. ${ }^{[1,2]}$ However, in some of these patients, early neurorrhaphy may not be reasonable because of the contaminated wound, the presence of concomitant vascular injuries, or the worse general condition of the patient due to other systemic injuries. In this condition, repair of the nerve transaction may require to be delayed for a few days or weeks. There are a few clinical and experimental studies comparing the results of immediate versus delayed ( $>4$ weeks) repair of the nerve in literature. However, there is not much information about the results of the subacute repair of the transected peripheral nerves.

Cite this article as: Tufan A, Karagöz Güzey F, Eren B, Taş A, İşler C, Kahraman Akkalp A, et al. Immediate versus delayed primary repair of the sciatic nerve in a nerve transaction model in rats. Ulus Travma Acil Cerrahi Derg 2020;26:361-365.

Address for correspondence: Azmi Tufan, M.D.

Sağlık Bilimleri Üniversitesi, Bağcılar Eğitim ve Araştırma Hastanesi, Nöroşirurji Kliniği, İstanbul, Turkey

Tel: +90 212 - 4404000 / 3313 E-mail: tufanazmi@gmail.com

Ulus Travma Acil Cerrahi Derg 2020;26(3):36I-365 DOI: 10.14744/tjtes.2019.48579 Submitted: 28.06.2019 Accepted: 23.10.2019 Online: I5.05.2020

Copyright 2020 Turkish Association of Trauma and Emergency Surgery 
In this study, we aimed to evaluate the effects of immediate versus subacute, or with the term frequently used in literature, delayed primary (after seven days) repair of peripheral nerve injury ${ }^{[3]}$ on histological results of axon degeneration and weights of end-organ muscles in a transaction type sciatic nerve injury model in rats.

\section{MATERIALS AND METHODS}

This study was approved by the BADABEM (the local ethical committee for experimental studies in our hospital) $\left(24^{\text {th }}\right.$ September 2014/number 10). In this study, 28 female WistarHannover rats weighing 250-300 g were used. All animals were maintained on a 12-h light/dark cycle with an average room temperature of $22^{\circ} \mathrm{C}, 30 \%$ humidity and with food/water available ad libitum.

\section{Experimental Groups}

The subjects were randomly introduced into the four groups as follows:

Group I: Immediate repair group $(n=8)$ : Left sciatic nerve was transected and sutured immediately.

Group 2: Delayed primary repair group $(n=8)$ : Left sciatic nerve was transected and sutured 7 days later.

Group 3: Sham-operated group $(n=6)$ : Left sciatic nerve was explored, but not transected.

Group 4: Control group $(n=6)$ : Left sciatic nerve was transected but not sutured.

\section{Operations}

Operations were performed under general anesthesia using intraperitoneal ketamine and xylazine injection. After standard exploration of the left sciatic nerve, it was transected with scalpel number 15. In Group I, the nerve ends were sutured with $8 / 0$ monofilament nylon suture material from perineurium. For all neurorrhaphy, four separated sutures were placed. In Groups 2 and 4, the nerve was transected and both ends were sutured to the fascia of the gastrocnemius muscle from their perineurium. In Group 2, rats were anesthetized in the same manner one week later. The gap between the proximal and distal nerve ends was measured as $\mathrm{mm}$ after the tagged sutures were removed, and the nerve stumps were sutured to each other with the same manner as in Group I. In Group 3, the sciatic nerve was explored but not transected. In Group 4, the tag sutures were removed and the gap between the nerve ends was measured before killing the subjects eight weeks after transaction.

All animals were killed with intraperitoneal pentothal injection eight weeks later. Both legs were observed and then left sciatic nerve sample $6 \mathrm{~mm}$ in length that centered the repair site was taken out in Groups I, 2 and 4. In Group 3, the sample was taken from the similar site that the transaction was performed in the other groups. Both left and right gastrocnemius muscles were also taken out (Fig. I). Muscles were weighed on a sensitive scale.

\section{Histological Evaluation}

All evaluations were made under a light microscope by the same pathologist.

The sciatic nerve samples were fixed in 10\% formaldehyde and routinely processed for paraffin embedding. Four $\mu$ thick sections were obtained and stained with hematoxylin-eosin for evaluating myelin vacuolization, axon irregularity and inflammation/edema. They were scored as follow: 0: negative, +: mild, ++: moderate, and +++: high. For statistical analysis, the parameters were also scored by assessing the percentage of the degeneration by $10 \%$ intervals (ranging from $0 \%-100 \%)$.

Neurofilament immunohistochemistry and toluidine histochemistry were also performed to find out the nerve clearly.

\section{Statistical Evaluation}

Mean values and standard deviations were calculated for numerical data. $F$ test was used to determine the distribution of the numerical data, and Student's t-tests were used to compare numerical data of the groups. Mann-Whitney $U$ test was used to compare the ordinary data. It was accepted as significant if $\mathrm{p}<0.01$.

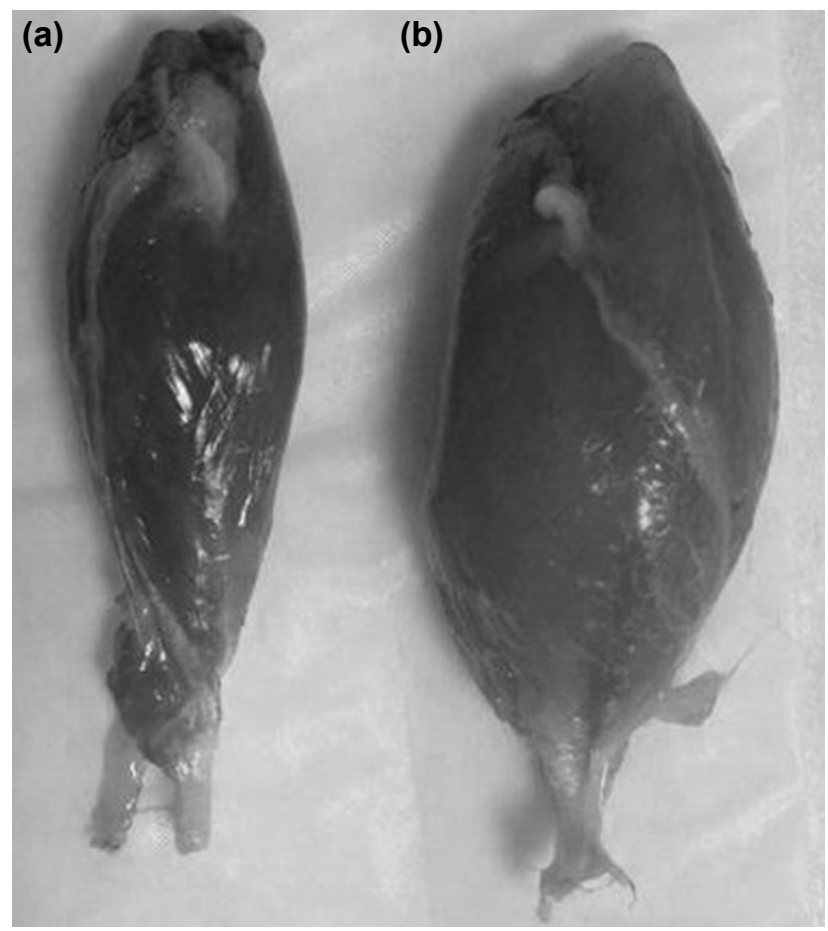

Figure 1. The left (a) and right (b) gastrocnemius muscles of a subject from Group 4. 


\section{RESULTS}

A subject was lost during the study period in Group 2 and excluded from this study.

\section{Observations}

Neurorrhapy in Group I was easier than to be in Group 2 because there were more adhesions in Group 2. However, neurorrhaphy was accomplished in all subjects of both groups. There was atrophy of the left leg and compression wounds in the left foot of all subjects of Group 4 at the end of the eight weeks.

\section{Measurements of the Gap}

The gap between proximal and distal ends of the transected nerve was $<4 \mathrm{~mm}$ (mean $2.75 \mathrm{~mm}$ ) in all subjects of Group 2 during neurorrhaphy one week later, however it was $>4 \mathrm{~mm}$ (mean $7 \mathrm{~mm}$ ) in all subjects of Group 4 during the collection of the nerve samples eight weeks later $(p<0.00 \mathrm{I})$ (Table I).

\section{Weights of the Muscles}

The weights of the left gastrocnemius muscles were not statistically different in Groups I and $2(p=0.57)$. However, the left gastrocnemius muscles were significantly lighter in both of the study groups (Groups I and 2) than to be in Group $3(p<0.001)$, and significantly heavier than to be in the Group $4(p<0.001$ and $p=0.0017$, respectively). In Groups I, 2 and 4 , the left muscle was lighter than the own right muscle ( $p<0.00$ I for Groups I and 4 and $p=0.007$ for Group 2). The weights of the left and right muscles were not statistically sig-

Table I. Measurements of the gap between the nerve stumps and histological grades of axonal degeneration of the groups were given

\begin{tabular}{lcccc}
\hline & Group I & Group 2 & Group 3 & Group 4 \\
\hline $\begin{array}{l}\text { Gap (distribution/ } \\
\text { mean mm) }\end{array}$ & NA & $2-4 / 2.75$ & NA & $5-8 / 7$ \\
$\begin{array}{l}\text { Histological grade } \\
\text { (distribution/median) }\end{array}$ & $20-50 / 35$ & $20-60 / 40$ & $0-5 / 5$ & $50-60 / 60$ \\
\hline NA: Not applicable. & & & & \\
\hline
\end{tabular}

Table 2. The weights of the right and the left gastrocnemius muscles of the groups were given

\begin{tabular}{lcccc}
\hline & Group I & Group 2 & Group 3 & Group 4 \\
\hline Right & 1.765 & 1.64 & 1.56 & 1.55 \\
Left & 0.87 & 0.95 & 1.79 & 0.38 \\
$\mathrm{P}$ & $<0.001$ & 0.007 & 0.02 & $<0.001$ \\
\hline
\end{tabular}

The weights were given as $\mathrm{mg}$. The significant $\mathrm{p}$ values were shown as bold and italic characters.

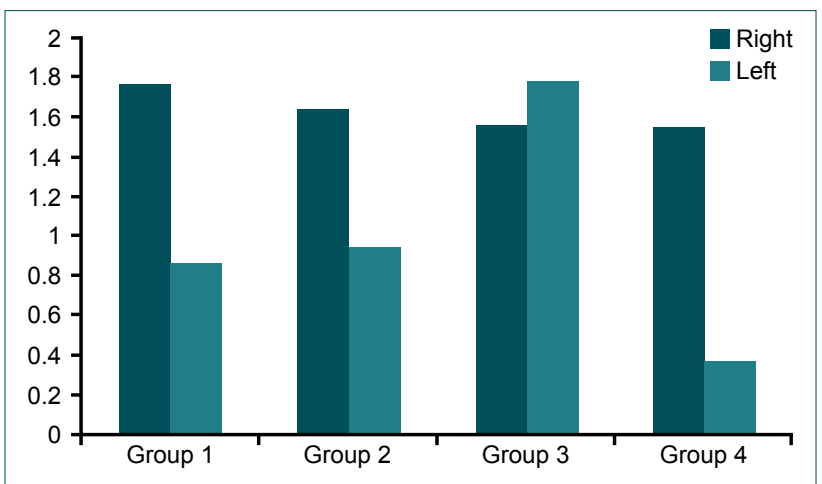

Figure 2. The graphic showing the mean weights of the right and left gastrocnemius muscles as $\mathrm{mg}$ in the groups.

nificant in Group $3(p=0.02)$. The mean weights of the muscles were given in Table 2 and shown in Figure 2.

\section{Histological Findings}

The score of the axon degeneration was significantly lower in Groups I and 2 than to be in Group $4(p<0.01)$, and significantly higher than to be in Group $3(p<0.01)$. There was not a statistically significant difference between Groups $I$ and 2 $(p=0.68)$ (Table I).

\section{DISCUSSION}

Peripheral nerves have a relatively good regeneration capacity according to the central nervous tissue. However, this capacity is usually inadequate in the complete or nearly complete nerve injuries. In this condition, surgical nerve repair is mandatory and primary end-to-end neurorrhaphy is preferable. ${ }^{[I]}$ The aim of surgery is to get facing each other of the fascicles of the proximal and distal nerve stumps according to their functions. The motor fascicles of the proximal nerve stump must be joined to the motor fascicles of the distal nerve stump, and the sensory ones must be joined to the sensory fascicles.

Timing of repair is one of the most important factors affecting the regeneration of the injured nerve and recovery of its motor and sensory functions. If the nerve is cleanly injured by a sharp object, immediate repair is a preferable timing as there is no scarring, with clear fascicles ends, the short gap between the nerve stumps and intraoperative stimulation of the distal nerve can be performed in the early period of the injury. ${ }^{[4]}$ In addition, early rehabilitation can be started if the early repair is done. ${ }^{[5]}$ However, the peripheral nerve injuries are frequently associated with the vascular injuries, the wound may be contaminated, or the general condition of the patient may not be good due to other systemic injuries. Thus, the repair of the nerve may not be performed during a few days after injury. In addition, better operation conditions, such as more favorable suture materials, microsurgical equipment, and the most importantly, a more experienced surgeon, can provide in a few days if the nerve repair does not perform immediately. ${ }^{[6]}$ 
There are some clinical and experimental studies that compare the results of early and late (usually more than after four weeks) repair. ${ }^{[7-9]}$ jivan et al. ${ }^{[9]}$ reported that the clinical results were significantly better if the brachial plexus injuries were repaired in shorter than two weeks. Erakat et al. ${ }^{[8]}$ reported that the injury to surgery interval is the most significant prognostic factor in a study evaluating the timing of repair of the lingual nerve injury. Gezercan et al. ${ }^{[3]}$ reported in a series consisting of 25 nerve injuries repaired 3-30 months after the injury that only $23.4 \%$ of the cases had $4-5 / 5$ motor strength at the end of a 15 month follow-up period. There are some studies reporting better clinical results with early primary repair than delayed repair for upper extremity nerves. ${ }^{[10-12]}$ Ruijs et al. ${ }^{[13]}$ reported in a meta-analysis of 23 series consisting of 623 median and ulnar nerve injuries that delay in surgery was a negative predictive factor, and its effect gradually increased per month.

In recent studies on intracellular signaling pathways initiating rapidly after peripheral nerve injuries, early repair of the nerve has clear advantages. ${ }^{[2]}$ Saito and Dahlin ${ }^{[7]}$ reported in an experimental study that if the repair delays over 30 days, nerve regeneration impairs. It was reported that the decrease in the number of Schwann cells expressing the transcription factors with time after the injury has a negative effect on axonal growth. ${ }^{[2,14,15]} \mathrm{Fu}$ and Gordon et al. ${ }^{[16]}$ also reported in an experimental study that the rate of reinnervation of the muscles was significantly higher in the subjects whose nerves were repaired immediately than to be in the subjects whose nerves were repaired six months later. Jonsson et al. ${ }^{[14]}$ reported an experimental study evaluating the effects of delayed peripheral nerve repair on nerve regeneration and target muscle recovery and they did not found any difference for numbers of regenerated axons between the immediate and the one-month repair groups. However, axonal area was statistically smaller in the one-month repair group.

There is only one study comparing the results of immediate and delayed primary repair of the complete sectioned nerve in literature. Piskin et al. ${ }^{\left[{ }^{[7]}\right.}$ reported a rabbit study evaluating the results of early versus three days later, primary repair of the sciatic nerve injury. They did not find any histological and stereological difference between two-timing.

In this study, we chose the $7^{\text {th }}$ day after the injury as "subacute" or "delayed primary" repair time for two reasons: One of them was that this time span is usually sufficient to make ready the patient for the operation in ideal conditions, and the second was that we want to take advantage of the stimulating capacity of the distal Schwann cells. After the complete section of the nerve, the Schwann cells increased in number and they significantly expressed nerve growth factor (NGF) receptors at the distal portion of the nerve in a few days after nerve injury. Activation of these receptors stimulates the regeneration of axonal sprouts. ${ }^{[1]}$ In a study, it was shown that the level of NGF receptors increased to 50 fold from the baseline level seven days after injury. ${ }^{[18]}$ However, denervated Schwann cells gradually lose their ability to support the growing axons in time if there is no connection between the newly sprouting axons. ${ }^{[19]}$

The results of our study demonstrated that one week delay of the repair did not affect the histological results and weight of the muscle innervated by the nerve. These results were significantly better than to be in the control group without nerve repair, and they were significantly worse than to be in the sham-operated group without the nerve section, as expected. These results were thought that delayed primary repair of the totally sectioned peripheral nerve for one week after the injury did not badly affect the regeneration of the nerve comparing to the immediate repair. Therefore, to delay the repair about one week is a logical choice until providing the optimal conditions in the cases cannot be operated immediately after injury due to various reasons.

If the nerve repair is delayed, the gap between the stumps of the nerve gradually increases due to the retraction and scar formation. This condition causes difficulty in primary repair. Moore et al. ${ }^{[4]}$ advocated tagging the nerve ends to the underlying fascia and muscle tissues to avoid the increase of the gap between the cut nerve ends till the repair if it is delayed. Wu et al. ${ }^{[20]}$ used this technique in an experimental model. We also performed this technique in the subjects of control and delayed repair groups immediately after the sciatic nerve section. In the delayed repair group, the gap was less than 4 $\mathrm{mm}$ in all subjects at seven days after injury. This distance is shorter than the $20 \%$ of the whole sciatic nerve length (about $2 \mathrm{~cm}$ ) in the rat. Sunderlund and Bradley ${ }^{[21]}$ reported that peripheral nerves could be lengthened about $20 \%$ of their whole length without any damage. Therefore, this timing is a good choice for primary repair of the peripheral nerve without stretching. In the control group, the mean gap between proximal and distal stumps of the nerves was $7 \mathrm{~mm}$, and it was $>4 \mathrm{~mm}$ in all subjects eight weeks after injury despite the presence of the tagged sutures.

\section{Conclusion}

Delaying the repair for one week as elective surgery did not badly affect the histological results and weight of the muscle that was innervated by the sectioned nerve compared to the immediate repair group in a sciatic nerve transaction model in rats. Therefore, it was thought that the repair of the transected nerves might be delayed about one week if the conditions related to the patients or centers are not optimum. However, it is required some clinical studies if these results are also valid for human patients or not.

Ethics Committee Approval: This study was approved by the BADABEM (the local ethical committee for experimental studies in our hospital) (24 $4^{\text {th }}$ September 2014/number 10).

Peer-review: Internally peer-reviewed. 
Authorship Contributions: Concept: A.T., F.K.G., V.A.Y.; Design: A.T., F.K.G., B.E., C.I., V.A.Y., M.Ç.; Supervision: F.K.G., V.A.Y.; Fundings: A.T., A.Taş., C.I., M.Ç.; Materials: A.T., A.Taş., M.Ç., V.A.Y., B.E., I.G., A.K.A.; Data: A.T., M.Ç., A.Taş., C.I.; Analysis: A.T., F.K.G., V.A.Y., M.Ç., C.I., I.G., B.E., A.K.A.; Literature search: A.T., F.K.G., A.Taş., M.Ç., V.A.Y., C.I., I.G., B.E., A.K.A.; Writing: A.T., F.K.G., B.E., A.Taş., C.I., A.K.A., I.G., V.A.Y., M.Ç.; Critical revision: A.T., F.K.G., V.A.Y., i.G., B.E., A.K.A., C.I., M.Ç.

\section{Conflict of Interest: None declared.}

Financial Disclosure: This study was supported by Bağcılar Training and Research Hospital.

\section{REFERENCES}

1. Campbell WW. Evaluation and management of peripheral nerve injury. Clin Neurophysiol 2008;119:1951-65. [CrossRef]

2. Dahlin LB. The role of timing in nerve reconstruction. Int Rev Neurobiol 2013;109:151-64. [CrossRef]

3. Gezercan Y, Menekșe G, Ökten Aİ, Arslan A, Özsoy KM, Ateş T, et al. The Outcomes of Late Term Surgical Treatment of Penetrating Peripheral Nerve Injuries. Turk Neurosurg 2016;26:146-52. [CrossRef]

4. Moore AM, Wagner IJ, Fox IK. Principles of nerve repair in complex wounds of the upper extremity. Semin Plast Surg 2015;29:40-7.

5. Sinha S, Khani M, Mansoori N, Midha R. Adult brachial plexus injuries: Surgical strategies and approaches. Neurol India 2016;64:289-96.

6. Nouraei MH, Hosseini A, Salek S, Nouraei F, Bina R. Median and ulnar nerve injuries; what causes different repair outcomes?. Adv Biomed Res 2015;4:215. [CrossRef]

7. Saito H, Dahlin LB. Expression of ATF3 and axonal outgrowth are impaired after delayed nerve repair. BMC Neurosci. 2008;9:88. [CrossRef]

8. Erakat MS, Chuang SK, Shanti RM, Ziccardi VB. Interval between injury and lingual nerve repair as a prognostic factor for success using type I collagen conduit. J Oral Maxillofac Surg 2013;71:833-8. [CrossRef]

9. Jivan S, Kumar N, Wiberg M, Kay S. The influence of pre-surgical delay on functional outcome after reconstruction of brachial plexus injuries. J Plast Reconstr Aesthet Surg 2009;62:472-9. [CrossRef]

10. Birch R, Raji AR. Repair of median and ulnar nerves. Primary suture is best. J Bone Joint Surg Br 1991;73:154-7. [CrossRef]

11. Leclercq DC, Carlier AJ, Khuc T, Depierreux L, Lejeune GN. Improvement in the results in sixty-four ulnar nerve sections associated with arterial repair. J Hand Surg Am 1985;10:997-9. [CrossRef]

12. Merle M, Amend P, Foucher G, Michon J. Plea for the primary microsurgical repair of peripheral nerve lesions. A comparative study of 150 injuries of the median or the ulnar nerve with a follow-up of more than 2 years. [Article in French] Chirurgie 1984;110:761-71.

13. Ruijs AC, Jaquet JB, Kalmijn S, Giele H, Hovius SE. Median and ulnar nerve injuries: a meta-analysis of predictors of motor and sensory recovery after modern microsurgical nerve repair. Plast Reconstr Surg 2005;116:484-96.

14. Jonsson S, Wiberg R, McGrath AM, Novikov LN, Wiberg M, Novikova $\mathrm{LN}$, et al. Effect of delayed peripheral nerve repair on nerve regeneration, Schwann cell function and target muscle recovery. PLoS One 2013;8:e56484.

15. Kuffler DP. An assessment of current techniques for inducing axon regeneration and neurological recovery following peripheral nerve trauma. Prog Neurobiol 2014;116:1-12. [CrossRef]

16. Fu SY, Gordon T. Contributing factors to poor functional recovery after delayed nerve repair: prolonged denervation. J Neurosci 1995;15:3886-95.

17. Piskin A, Altunkaynak BZ, Çitlak A, Sezgin H, Yazıcı O, Kaplan S. Immediate versus delayed primary nerve repair in the rabbit sciatic nerve. Neural Regen Res 2013;8:3410-5.

18. Taniuchi M, Clark HB, Johnson EM Jr. Induction of nerve growth factor receptor in Schwann cells after axotomy. Proc Natl Acad Sci U S A 1986;83:4094-8. [CrossRef]

19. Sulaiman OA, Gordon T. Effects of short- and long-term Schwann cell denervation on peripheral nerve regeneration, myelination, and size. Glia 2000;32:234-46. [CrossRef]

20. Wu P, Spinner RJ, Gu Y, Yaszemski MJ, Windebank AJ, Wang H. Delayed repair of the peripheral nerve: a novel model in the rat sciatic nerve. J Neurosci Methods 2013;214:37-44. [CrossRef]

21. Sunderlund S, Bradley KC. Stress-strain phenomena in human peripheral nerve trunks. Brain 1961;84:102-9. [CrossRef]

\section{DENEYSEL ÇALIŞMA - ÖZET}

\section{Sıçanlarda sinir transeksiyon modelinde siyatik sinirin acil ve gecikmeli primer onarımı}

\section{Dr. Azmi Tufan,, ${ }^{1}$ Dr. Feyza Karagöz Güzey, ${ }^{1}$ Dr. Burak Eren, ${ }^{1}$ Dr. Abdurrahim Taş, ${ }^{2}$ Dr. Cihan İşler, ${ }^{3}$ Dr. Aslı Kahraman Akkalp, ${ }^{4}$ Dr. İlker Güleç, ${ }^{1}$ Dr. Vildan Ayşe Yayla, ${ }^{5}$ Dr. Murat Çabalar ${ }^{5}$}

1Sağlık Bilimleri Üniversitesi, Bağcılar Eğitim ve Araştırma Hastanesi, Nöroşirürji Kliniği, İstanbul
${ }^{2}$ Sağlık Bilimleri Üniversitesi, Gazi Yaşargil Eğitim ve Araştırma Hastanesi, Nöroşirürji Kliniği, Diyarbakır
${ }^{3}$ Istanbul Üniversitesi-Cerrahpaşa, Cerrahpaşa Tıp Fakültesi, Nöroşirürji Anabilim Dalı, İstanbul
${ }^{4}$ İzmir Katip Çelebi Üniversitesi, Atatürk Eğitim ve Araştırma Hastanesi, Patoloji Kliniği, İzmir
${ }^{5}$ Sağlık Bilimleri Üniversitesi, Bakırköy Dr. Sadi Konuk Eğitim ve Araştırma Hastanesi, Nöroloji Kliniği, İstanbul

AMAÇ: Periferik sinir yaralanmasında cerrahinin zamanlaması hala tartışmalıdır. Periferik sinir hasarının derhal ve gecikmiş primer (yedi gün sonra) onarımının sonuçları değerlendirildi.

GEREÇ VE YÖNTEM: Wistar cinsi sıçanlar 4 gruba ayrıldı: Sinir keskin şekilde Grup I, 2 ve 4'te kesildi. Grup I'de hemen dikildi ve Grup 2'de yedi gün sonra dikildi ve Grup 4'te dikilmedi. Grup 3'te sol siyatik sinir sadece eksplore edildi. Sekiz hafta sonra, yaralanan sinir bölgesinden doku örnekleri alındı. Her iki gastrocnemius kasları tartıldı. Sinir örnekleri akson dejenerasyonu açısından incelendi. Miyelin vakuolizasyonu, akson düzensizliği ve ödem/enflamasyon parametreleri değerlendirildi.

BULGULAR: Acil ve gecikmiş primer onarım grupları arasında akson dejenerasyonu skoru ve gastrocnemius kasının ağırlığı açısından anlamlı fark yoktu. Bununla birlikte, bu parametreler her iki tamir grubunda da kontrol grubundan anlamlı derecede daha iyiydi ve sinir kesisi yapılmayan gruptan anlamlı derecede daha kötüydü.

TARTIŞMA: Sıçanlarda siyatik sinir transeksiyon modelinde onarımın yaklaşık bir hafta geç yapılması acil onarım ile karşılaştırıldığında, kesilmiş sinirin uyardığı kasın histolojik sonuçlarını ve ağırlığını etkilememiştir.

Anahtar sözcükler: Operasyon zamanlaması; periferik sinir; periferik sinir hasarı; sinir hasarı; iinir transeksiyonu. 